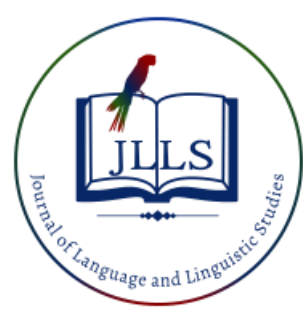

Available online at www.jlls.org

JOURNAL OF LANGUAGE AND LINGUISTIC STUDIES

ISSN: $1305-578 \mathrm{X}$

Journal of Language and Linguistic Studies, 17(3), 1266-1276; 2021

\title{
Comprehensive methods of reconstructing author's original work
}

\author{
Nazgul B. Ilyassova a ${ }^{\text {ID }}$, Berikbay Sagyndykuly ${ }^{\text {b iD, }}$, Bakytgul Kulzhanova ${ }^{\text {c iD }}$ \\ a,b,c Al-Farabi Kazakh National University, Almaty, Republic of Kazakhstan
}

\section{APA Citation:}

Ilyassova, N. B., Sagyndykuly, B., \& Kulzhanova, B. (2021). Comprehensive methods of reconstructing author's original work. Journal of Language and Linguistic Studies, 17(3), 1266-1276. Doi: 10.52462/jlls.90

Submission Date:22/05/2021

Acceptance Date:20/08/2021

\begin{abstract}
Dating back the period between XI-XV centuries, more precisely, before the formation of national languages, numerous relicts survived our era in the Arabic script. According to the unanimous opinion of turkologists, all these historical monuments were written in the Karluk-Uyghur, Oghuz, and Kipchak languages. However, Turkology has not determined yet the contribution of each language to a particular monument. Therefore, most monuments are only allegedly defined. Only statistical analysis can answer the question of how much the Oghuz, Kipchak and Karluk-Uyghur languages relate to each monument. Thus, the analysis is one of the most urgent issues. For the successful research, the importance of identifying similarities and differences in several copies of each monument is not less important. To compare three manuscripts of the "Hibat-ul-Haqaiiq" monument (The Gift of the Truth), to find the differences and to restore the author's originality as much as possible. The article proposes several ways to restore the author's original: a method of statistical analysis, methods of historical comparison, a method of component analysis. It was determined that the monument "Hibat-ul-Haqaiq" was written in the Turkic-Kipchak language, and not in the Karluk-Uygur language, as turkologists had previously claimed. If to apply our approach to analyze other monuments' manuscripts, great results are unfailingly achievable.
\end{abstract}

Keywords: "Hıbat-ul-Haqa1iq"; manuscripts; copies; author's original; similarities and differences

\section{Introduction}

Since experts who can read ancient Turkic writing (Figure 1) and distinguish its graphics at an adequate level are quite few even globally, unfortunately, the textology related to ancient Turkic written monuments cannot develop at its proper scale. Taking this into account, we compared three versions of Ahmed Iúginekı's so-called collection of didactic poems "Hibat-ul-Haqaiiq" (The Gift of Truth) written in the XII century. We named the manuscript copied in 1444 in the Uighur writing as A, the manuscript copied in 1480 in the Uighur writing and transcribed line-by-line in the Arabic script as $\mathrm{B}$, and the manuscript copied in the Arabic script with both unknown copyist and year as $\mathrm{C}$ versions (bin Mahmood, 1951). In this dedicated thesis, we found spelling, phonetic, lexical, morphological, and syntactical differences in the texts of these three manuscripts and explained the reasons for their

\footnotetext{
${ }^{1}$ Corresponding author.

E-mail address: n.ilyassova4549@tanu.pro
} 
occurrence (Iúgineki, 1985). Based on each difference individually, we determined as far as possible which version is the author's one. We tried to reconstruct the author's original work on a scientific basis. Finally, we composed a critical text that closest to the author's original version (Panferova \& Kim, 2021; Kobal \& Sofilkanych, 2020; Lavrenova \& Fodor, 2020).

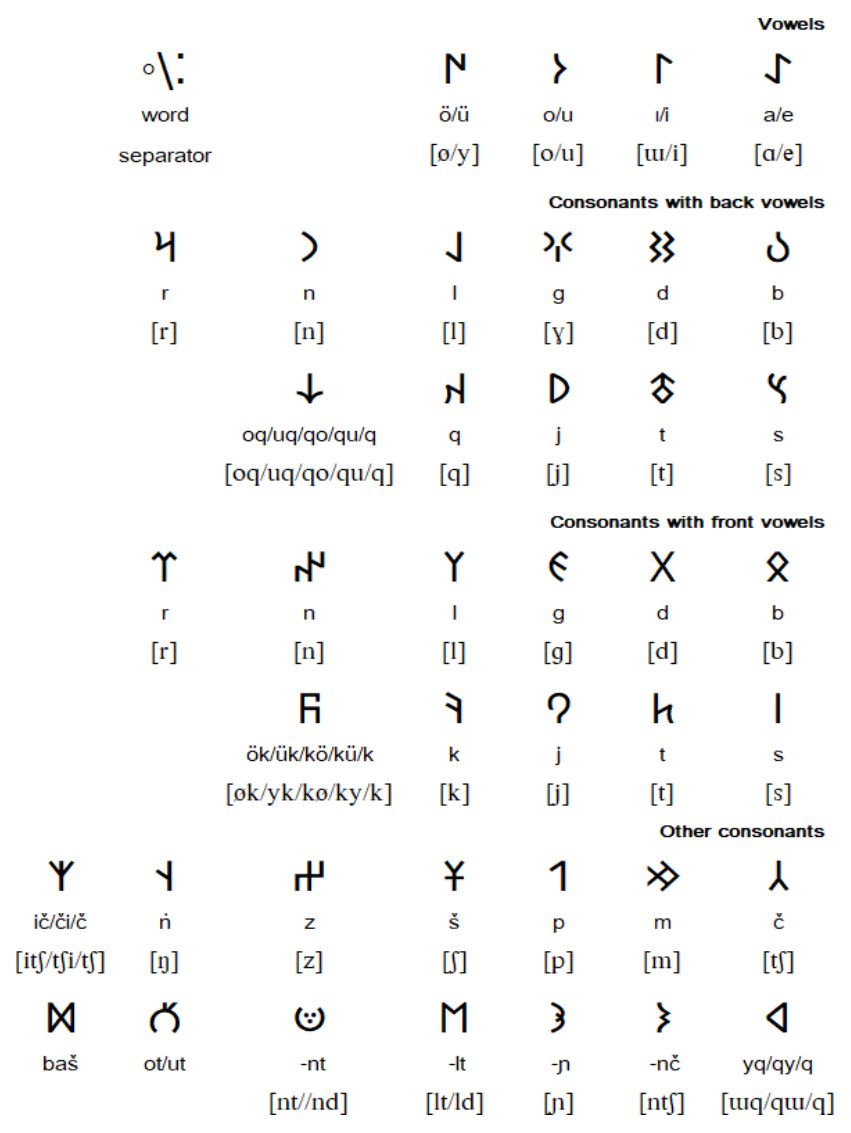

Figure 1. Old Turkic alphabet

Ahmed Iúginek1 called his poem "Hibat-ul-Haqaiq" and gave it as a gift to one of the rulers of the West Turkestan at the time - Dat Ispahsalar Bek. However, the copies existent in the days of the author and then written on a paper didn't reach our days. At the beginning of the XV century, Arslan Khozha Tarkhan, one of the most prominent emirs of Central Asia and patron of literature, had all the copies of the poem meticulously compared by experts, speaking today's language undertook textology work, and requested copyists to re-take copies as close as possible to the author's original work. The copy manuscripts we have today are the copies of the copy which Arslan Khozha Tarkhan commissioned to reconstruct. Textual comparisons show that as time progressed, copy after copy, the Arslan Khozha Tarhan's version started to lose its quality (Sepir, 1934).

How did mistakes occur when copyists copied from each other? More often than not, individual words cannot be deciphered between handwritings and replaced with another word in an approximated form or with an affix. Thereby, "salım til" (soft tongue) in the couplet 51 was turned into "Salımdın" (means Salım's) and words "al", "kel" in the couplet 293 were merged into the verb "algyl". Replacement of Turkic words with other Turkic words, as well as their alteration with Arabian or Persian words, were resulted from similar reasons (Akhmetzhanova, 1989; Ilyichev \& Fedoseyev, 1983; Lalak et al., 2019). 


\section{Literature Review}

In ancient times, poets, writers, and scholars had to share their works in manuscripts since no publishing houses existed. In this regard, a league of professional copyists evolved (Baranov, 1993; Gumilev, 1993; Kolshansky, 1990; Kondratyev, 1970; Pavenkov et al., 2018). Thanks to them, a wide variety of artifacts survived until the present. However, by passing from hand to hand, author's original work used to change beyond recognition. Considering that a great length of time elapsed since then, author's work often could not remain intact. Even the manuscripts of copyist who lived around the years of author's life were lost. In such a case, aside from the author's initial manuscript, it was not easy to find an eligible alternative, reconstructed, and close-to-original critical text (Polivanov, 1968). Nevertheless, the need for the author's first work gave life to textology. Gradually, its branch dealing with comprehensive and multidimensional analysis - linguotextology - started taking on momentum. Its main purpose is to compare the manuscript versions of ancient and oldest monuments that survived our times, to find language differences between them, to determine which differences are author's use and copyist's corrections and mistakes, and to reconstruct the author's work on a scientific basis. This is the only way to separate and distinguish the author's original work.

\section{Methodology}

We found it appropriate to publish a portion of our study as a research article. We transcribed the above-mentioned manuscripts into the Cyrillic to meet the requirements of local academic community. While transcribing, we faced a number of difficulties. For example, the Turkic word, which means "many" can be read in four varieties as per the Arabic alphabet: ógúsh, ókúsh, úgúsh, úkúsh. Which one of them is right? The poem's rhyme helps out. The distichs (couplets) 241-242 of the version B say (Sagyndykuly, 2002):

Bahıl 1yg̉dy zár sım haramdan ókúsh

Vabal kótrú bardy úzıla sókúsh.

A miser collected form a rascal lots of gold and silver,

And shouldered sin, took on curse on top.

All academic linguists transcript the word meaning "cursing, reprimand, accusation" which is found in Yenissey-Orhon, Old Uighur and Middle Ages monuments as sókúsh. Therefore, if it is correctly transcripted, the word "ókúsh" cannot be written in variations (ógúsh, ókúsh, úgúsh, úkúsh) as above (Malov, 1952). Various writing styles (graphics) can also help for this purpose. For example, if $\mathbf{t}$ and $\mathbf{d}$ in the Uighur writing are denoted by a single character, then in the Arabic writing - by two characters. Thus, one graphic character can correct the "defect" of another. Et cetera (Magsumov et al., 2019a; Magsumov et al., 2019b; Portnova, 2019).

Certainly, there are a lot of textology-related issues. All of them cannot be covered in a short article. In our research, we are going to talk about word collocations modified by copyists, chaotically edited and miscopied couplets. The couplet 51 of the versions $\mathbf{A}, \mathbf{B}$, and $\mathbf{C}$ of the monument say (Sag̉yndykuly, 2002):
A. Ra, 11atqa mýshfik salım tıl halım
To those under his wing he is gracious, his tongue is soft and he is courteous
B. Ra, 11atqa mýshfak Salımdın halım
To those under his wing he is gracious; courteous than Saltm
C. Ra, 11atqa mýshfiq Salımdın halım 
To those under his wing he is gracious; courteous than Sallm

The difference is that the collocation "salım tıl" (soft tongue) in the version A was changed to a man's name in versions $\mathbf{B}$ and $\mathbf{C}$ and took the form "Salımdın". The word "t1l" in the author's original work was probably perceived by copyists as an ablative case ending -tın/-dın. They added it to the then widely spread name Salım. For this reason, this couplet put on a different look. Here, Ahmed Iúginek1 is talking about the extremely gentle tongue and courteous behaviour of Ispahsalar bek, he is speaking words of praise about. It is a copyist's mistake out of misunderstanding to replace the adjective in this collocation with a name. The author of the monument compared his hero to the most glorious people in Muslim history. Among them, there is no man named Salım. One version usually reveals such kind of awkward errors in another. There is no doubt that the couplet in the version $\mathbf{A}$ is correct. Let us have a look at the couplet 77 (Sagyndykuly, 2002):

\section{A. Bezadım kitabny navadır sózún}

I decorated the book with amazing words.

\section{B. Bezadım kıtabny mavı, iz masal}

I decorated my book with sermon examples

C. Bezadım kitabny mava, ız masal

I decorated my book with sermon examples

In the version $\mathbf{A}$, the collocation "navadır sózún" is replaced by "mava, $1 \mathrm{z}$ masal" in the versions $\mathbf{B}$ and C. "Navadır" means "rare, amazing". While "mava, $1 \mathrm{z}$ masal" is translated as an "example of sermon". In very deed, the expression in the versions $\mathbf{B}$ and $\mathbf{C}$ is not any elegant than in the version $\mathbf{A}$. The couplet 447 has the sentence "Bitıdım kitaby mav1, 1z masal" (I finished the book of sermon examples). It looks like that copyists considered the epithet "mawa, $1 \mathrm{z}$ masal" more appropriate than "navadır sózún". In other words, it seems they changed it deliberately. Firstly, in the couplet 447, "mava, $1 z$ masal" is semantically compatible with the verb "bitıdım", but with the verb "Bezadım" in the versions $\mathbf{B}$ and $\mathbf{C}$ it is not. Secondly, the verb "Bezadım" (I personal) requires the instrumental case ending. In the versions $\mathbf{B}$ and $\mathbf{C}$, the sentence is short-cut because "mava, $1 \mathbf{z}$ masal" does not include the functional word "birla" meaning instrumental case or or "-yn" ending. In the version A, the root of the word "seaz" is added with -ún ending of the instrumental case to end up with seaz+ún word form. Hence, the couplet 77 of the version A is Ahmed Iúginekı's original work (Portnova, 2020; Portnova, 2017).

The couplet 146 of the versions (Sagyndykuly, 2002):

A. Tılındın kım edgú kım esız erúr

By the tongue is whoever virtuous or worthless.

B. Bý tıldın edgú kım esız erúr

From that tongue is whoever virtuous or worthless.

C. Bý tıldın edgú kım esız erúr

From that tongue is whoever virtuous or worthless.

In the version $\mathbf{A}$, the word form "tılındın" was replaced in the versions $\mathbf{B}$ and $\mathbf{C}$ by the "bý tıldın" collocation with a mental stress. Thus, copyists probably aimed at refining the couplet elegance. However, the plot of the work completely denies it. The preceding couplet 145 says "Ne kim kelsa erga tılındın kılúr" (Whatever comes to a man, is brought by his tongue). Here, the form "tılındın" was simply repeated in the couplet 146 as per the original version. Thus, the demonstrative pronoun "bu" is 
an insert word added by copyists. In this couplet, one word was made into two. On the contrary, there are facts of making one word from two. The couplet 293 (Sagyndykuly, 2002):

A. Iáma pandım al kel ýzatpa amal

And take the mind, come, do not multiply tricks.

B. Iáma pandım alg̀yl ýzatma amal

And take my mind, do not multiply tricks.

C. Iáma pandım alğyl ýzatma amal

And take my mind, do not multiply tricks.

The parenthesis "kel" in the version A was replaced by the imperative suffix -gyl in versions B and C. If to comb out the monument thoroughly from beginning to end, the author deliberately used parenthetic words like "bil" and "kel" to put a mental stress. It means that it is Ahmed Iúginekı's signature style. If we compare "pandım al" and "pandım algyl", one is predominantly commanding while another is a kind request or asking a favor. It is likely that the copyists read the word "kel" wrong and turned it into -gyl. Otherwise, there was no need to change words in this couplet. The poet through the parenthesis "kel" means "come to reason". But copyists "swallowed" this concept in its entirety. The verb "al" faded too because of the added -gyl ending. In such way copyists used to severely damage the author's original work (Gurianov, 2020; Ermachkov et al., 2021).

The couplet 362 of the versions $\mathbf{A}, \mathbf{B}$, and $\mathbf{C}$ of the says (Sagyndykuly, 2002):

A. Necha pýr hýnarlyqda bır aıb olýr

Even a notable craftsman has a flaw.

B. Necha pýr hýnarda bırar, aıb bolýr

Even a notable craftsman has a flaw or two.

C. Necha pýr hýnarda birar, aıb bolýr

Even a notable craftsman has a flaw or two.

In the version A, the phrase "Necha pýr hýnarlyqda" (even a notable craftsman) was replaced in the versions $\mathbf{B}$ and $\mathbf{C}$ with "Necha pýr hýnarda" and since the number of syllables was insufficient, the word "bir" (one) was changed with the wordform "birar" (one or two). However, both replacements were wrong. This can be proved by the following couplets 363 and 364: "Bý bır aibdın ótrú basyn kesgúch1, Ajýnda tırılgú kıshısız qalýr" (He who beheads for a flaw, Will be left alone with no single human being on earth). If the author had used "birar" (one or two), it would surely have been repeated in the next couplet, but only "bir" (one) was repeated. Secondly, the word "hunar" does not have a "human" seme, so it is absolutely incompatible with the phrase "he who beheads". But the word "craftsman" has the "human" sema. In short, the couplet in the version A was copied correctly. It does not conflict with further couplets.

\section{Results and Discussion}

We grouped and analyzed substantial errors, such as replacing a particular word by a different word with a meaning not anywhere near, replacing one phrase with another one failing to stick to the work's plotline. We conducted an analysis and found out which is right and wrong. In addition, there are abundance of misinterpretations of even the whole sentence. Now it is the turn of the misinterpreted and miscopied couplets in the copyists' manuscripts. The following truth was revealed when they were thoroughly passed through the sieve of reflection and profound scientific research.

The couplets 127 and 128 (Sag̉yndykuly, 2002): 
A. Tavarsyzg̉a bilıgı týkanmas tavar

Nasabsýzğa bilııı tukánmáz nasab

He who has no wealth, knowledge will become his untethered wealth

He who has no blessing, knowledge will become his untethered blessing

B. Tavarsyzg̉a biligı tukánmás tavar

\section{Hisabsyzǵa bılıglı ıarylmas hısab}

He who has no wealth, knowledge will become his untethered wealth

He who has no money, knowledge will become his inseparable money

C. Tavarsyzg̉a biligli tugánmas tavar

Hisabsyzǵa biliglı larylmas hisab

He who has no wealth, knowledge will become his untethered wealth

He who has no money, knowledge will become his inseparable money

The couplet 128 in the version $\mathbf{A}$ and versions $\mathbf{B}$ and $\mathbf{C}$ are absolutely incompatible with one another and edited entirely. Because the word "nasab" is a homonymous expression meaning in the Kazakh language "nesibe" (blessing) as well as "shejire" (pedigree). Copyists were absolutely unaware of the word "nesibe" and probably could not fit the word "shejire" in the couplet; instead, they invented and added "money". "Tavar" along with "livestock" also includes the notion of "money". In this chapter of his poem, Ahmed Iúginek1 is speaking about "food, subsistence" not "money". People often call food "nesibe" (blessing). It is unknown whether the copyist of the version A understood or not the meaning of this word. But the copy manuscript is correct. There is no difference in the first line of the couplet (127) in all three versions.

The couplets 187 and 188 (Nadelyaev et al., 1969):

\section{A. Chygaılyq ıarynlyq azýq ıqlýqy}

Chygarlyq tep a1ma tavar 1oqlýqyn

Poverty is a lack of food for a day to come

Do not say poverty is a lack of wealth

\section{B. Bý ballyq chygarlyq azýq 1oqlýg̉y}

Chygarlyq tep aıma azýq 1oqlýgyn

This wealth poverty is a lack of food

Do not say poverty is a lack of food

\section{Bý baılyq, chyghajlyk ıdı kısmaty}

Chyğarlyq dep aıma azýk 1oqlýgyn

This wealth poverty is the Creator's will

Do not say poverty is a lack of food

In the version A, the message which the monument's author wished to get across was conveyed in full. There is no fallacy in logical consistency, grammatical structure of sentences, and stylistic progression. The versions $\mathbf{B}$ and $\mathbf{C}$ entirely confused these two couplets. The couplet "Bý barlyq chygarlyq azýq 1oqlýgy" in the version $\mathbf{B}$ was copied with mistakes and consequently, the words have no semantic link with each other, its content is unclear, it is just a bag of words. The first line says that "poverty is a lack of food" but then holds against and goes on to say "Do not say poverty is a lack of food". In short, the version B confused two couplets from start to finish. The copyist of the version $\mathbf{C}$, 
perhaps his forbear, wrote "Bý ballyq, chyghajlyk 1d1 k1smaty" in the couplet 303 instead of "Chygaılyq 1arynlyq azýq 1oqlýqy" in the couplet 187 and made an inappropriate mistake. For this reason, this couplet line is repeated twice throughout the poem (couplets 187 and 303). In this manuscript $\mathbf{C}$, the couplet "Chygallyq tep a1ma tavar 1oqlýqyn" in its correct form in the version $\mathbf{A}$ was transformed into the distorted "Chyggallyq tep aima azýq 10qlýgyn". In short, both in B and C versions, couplets 187-188 were copied inconsistently (Sagyndykuly, 2011; Gurianov, 2016; Lapshina, 2019). It is good that the version A preserved the author's version.

The couplet 312 (Sagyndykuly, 2002):
A. Ekı qol dınarny ol ých qol qolýr
If there are two handfuls of dinars, he wishes three
B. Ekı qol dınarnı ol on qol qylýr
If there are two handfuls of dinars, he will make ten
C. Ekı pýl dınarnı ol on pýl qylýr
If there are two dinars of money, he will make ten

In this couplet, Ahmed Iúginek1 placed Prohet Muhammad's (blessings and peace of Allah be upon him) hadith: "Had the son of Adam two valleys full of gold he would yearn for a third" in his poem's lines. Either unaware of the hadith or treated it frivolously, anyway, the copyists of the versions $\mathbf{B}$ and C completely distorted the message to be sent. Secondly, while the copyist of the version B changed ých qol (three handful) to on qol (ten handful), the copyist of the $\mathrm{C}$ version changed to on pýl (ten dınars of money). Besides, he then renovated the phrase "ekı qol" (two handful) as "ek1 pýl" (two dinars of money) to frame the sentence correctly. In short, the idea and words of the Prophet about human greediness were ignored and construed by the copyists in their own way. And again, the version A saves the poem from distortion this time (Karasayev et al., 2019a; Karasayev et al., 2019b).

The couplet 390 (Sağyndykuly, 2002):

\section{A. Kedın kúnda hair ısh ma kótrúlgúlúg}

In these days, good deeds are raised and went away

\section{B. Kónı keldúgúncha haır ketgúlúg}

While the truth is still to come, the goodness is to go away

\section{Kónı keldúgúncha haır ketgúlúg}

While the truth is still to come, the goodness is to go away

The couplet 390 of the version $\mathbf{A}$ is not aligned with the idea of the poem, moreover, it is not rhymed with the verses preceding the word "kótrúlgúlúg". While the last word "ketgúlúg" in the versions $\mathbf{B}$ and $\mathbf{C}$ is rhymed with "yedgúlúg" in the couplet 389 . The idea in the versions $\mathbf{B}$ and $\mathbf{C}$ was correctly constructed: it is the idea of the poem's author. The idea in the couplet 390 of the version A is a misleading statement added by the copyist himself. This means that the version $\mathbf{A}$ cannot be relied on all the way (Kartskhiya et al., 2021; Zholmakhanova et al., 2018; Lapshina \& Eshchin, 2020).

The couplet 402 (Sagyndykuly, 2002):

\section{A. Ne ıerka ıygar baz senı ne tylyn}

What language with and what ground to will knock you again

\section{B. Iúrúgıl tılágıl ózún’ hoshlugynn}

Rejoice. Pray for your elation.

\section{Iúrúgıl tılágıl ózún hoshlugyn’}




\section{Rejoice. Pray for your elation.}

This time, in contrast to the above, the copyists of the versions $\mathbf{B}$ and $\mathbf{C}$ supposedly did not fully comprehend the couplet 402 and completely took out the author's warning "for now, live as you want", destiny "what language with and what ground to will knock you again". Instead, they praised those tempted into bad ways with words like: "Rejoice. Pray for your elation". Such contradictory and erroneous copies undermine and make worthless author's noble ideas. That's exactly what textology researches are for (Yıldırım, 2020; Yensenov et al., 2019; Kyzdarbekova et al., 2014).

The incomprehension of some words in the poet's original text made a copyist to add his own words. For example, in the couplet 128, the word "nasabsýz" was unclear, that's why the copyist replaced it by the Arabic word "hisabsýz". For that reason, the whole verse was rebuilt. This seriously damaged the author's idea to convey. We gave some examples of such mistakes in our research article above.

Inability to understand the author's intentions can lead to even grave mistakes. For example, in the couplet 402 of the version A, "Ne 1erka 1ygar baz senı ne tylyn" (What language with and what ground to will knock you again) was replaced in the versions $\mathbf{B}$ and $\mathbf{C}$ with "Iúrúgıl t1lágıl ózúng hoshluğyn'" (Rejoice. Pray for your elation) which is incompliant with the poem's spirit. Ahmed Iúginek1 satirized those devoid of humanity, cunning rascals, and immoral persons and warned them of landing finally in trouble should they kept acting like that. The copyists of the versions $\mathbf{B}$ and $\mathbf{C}$, on the contrary, render honors to those went awry and tell them keep celebrating. If the manuscripts of the "Hibat-ul-Haqaiq" (Figure 2) monument were not preserved, it would not be possible to correct this omission.

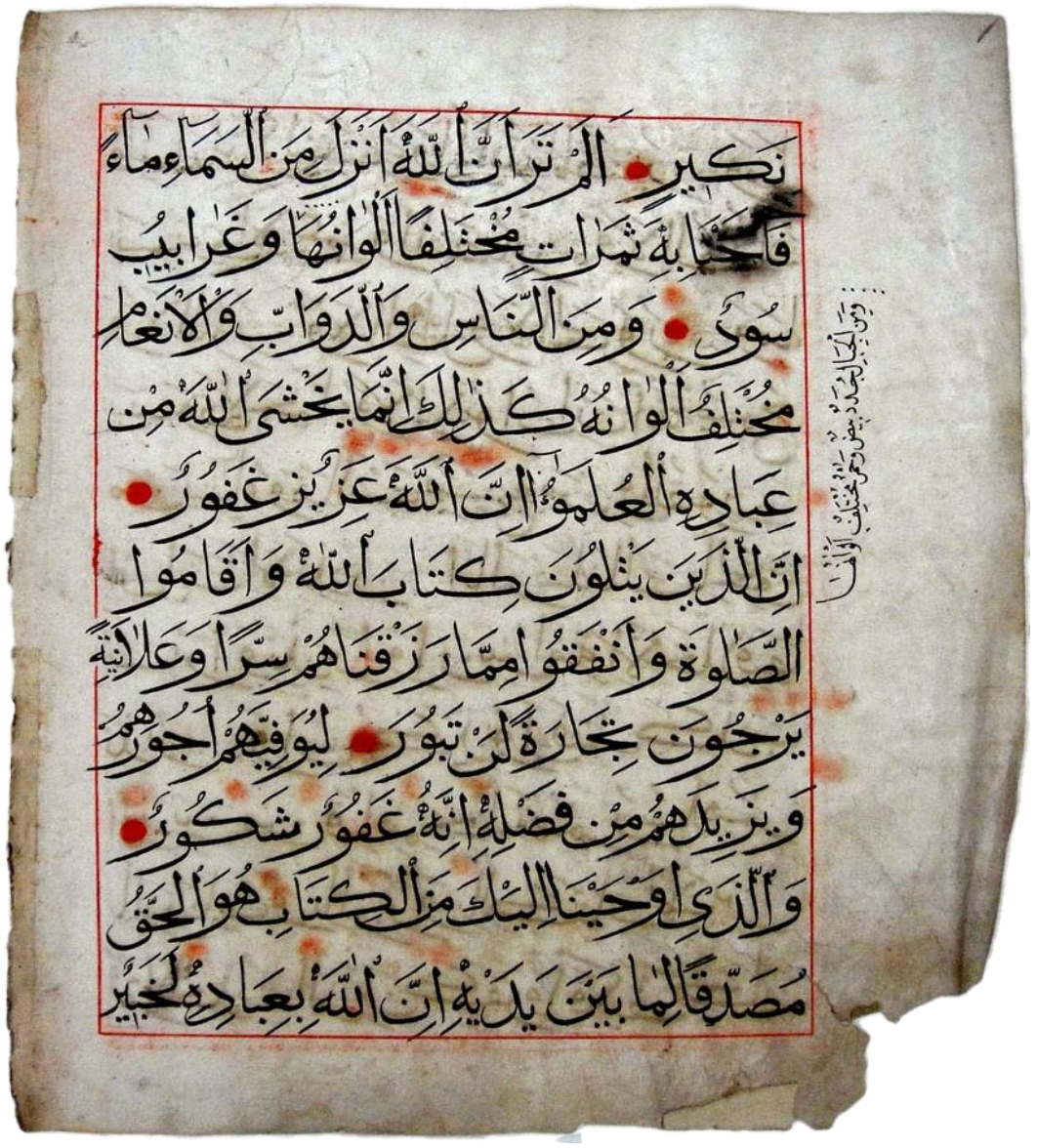

Figure 2. Manuscript of the "Hibat-ul-Haqaiiq" 
Copyists' negligence too is the reason of some mistakes. For example, the copyist of the version $\mathbf{C}$ in the couplet 303, wrote "Bý ba1lyq, chyghajlyk 1dı k1smaty" (This wealth, poverty is the Creator's will) instead of "Chygarlyq 1arynlyq azýq 1oqlýqy" (Poverty is a lack of food for a day to come), thus making a very embarrassing mistake. This created a nonsense. In short, the reasons for the omission and errors are different. We will elaborate all of them in our thesis researches.

\section{Conclusions}

For textology researches, it is best to have manuscripts as much as possible. Because in most cases, a mistake made by one copyist is not repeated by another. A line edited by one is not edited by another. Lines missing with one, present with another. Et cetera. If there are differences on some pages of manuscripts, there are innumerable ways to distinguish which of them is author's original text and which ones are added by copyists. For example, if to pay close attention to poem rhymes, it is possible to identify many improper adjustments. If an adjustment is in one version only and not encountered in others, then the version of frequent occurrence is the correct one. The frequency of word use throughout the work also helps to make the right decision. The content, style and theme of the work lay bare many errors made by copyists. Phonetic, morphological, and semantic phenomena, collocability of words, and other consistent patterns also help find the author's exact idea. The deeper is researcher's knowledge, the better is the quality of textology works.

\section{References}

Akhmetzhanova, Z. K. (1989). Functional-semantic fields of the Russian and Kazakh languages. Almaty: Nauka.

Baranov, A. G. (1993). The functional-pragmatic conception of text. Rostov-on-Don: Izdatelstvo RGPU.

bin Mahmood, E. A. (1951). Atevat-ul-Haqaık. Istanbul: Rashid Rahmetı Arat.

Ermachkov, I. A., Koroleva, L. A., Mineeva, E. K., \& Balanyuk, L. L. (2021). Slave trade in circassia (first half of the XIX century): Some characteristic features. Bylye Gody, 58(4), 2464-2470.

Gumilev, L. N. (1993). The ancient Turks. Moscow: Nauka.

Gurianov, P. A. (2016). Causes of ransom private railways in the Russian Empire during the reign of Alexander III. Bylye Gody, 39(1), 173-182.

Gurianov, P. A. (2020). Ransom of private railways in the Russian Empire during the era of Emperor Alexander III. Voprosy Istorii, 2020(9), 17-34.

Ilyichev, L. F., \& Fedoseyev, P. N. (eds.). (1983). Philosophical encyclopedic dictionary. Moscow: Soviet Encyclopedia.

Iúgineki, A. (1985). Transcriptsy, Kazakh auction, photocopying. Almaty: Ğylym.

Karasayev, G. M., Yensenov, K. A., Zhumagulov, B. S., Aldabergenov, K. M., \& Batkeeva, B. T. (2019a). The historical aspects of economic and legal international relations of independent Kazakhstan and China (1991-1997). Journal of Advanced Research in Law and Economics, 10(5), 1444-1451.

Karasayev, G. M., Zhaxygeldinov, Z. N., Yensenov, K. A., Naimanbayev, B. R., \& Bakirova, Z. S. (2019b). The place and history of the activities of Kazakhstan in the united nations organization (1991-2016). Journal of Advanced Research in Law and Economics, 10(7), 2008-2016. 
Kartskhiya, A. A., Tyrtychnyy, S. A., Smirnov, M. G., \& Dolgikh, M. G. (2021). Formation of the Russian oil industry in the 19th century: Historical experience and modern assessments. Bylye Gody, 58(4), 2471-2484.

Kobal, V. I., \& Sofilkanych, M. I. (2020). Uzhhorod Children's School of Arts formation and development as an important center of aesthetic education of school youth. Scientific Bulletin of Mukachevo State University. Series "Pedagogy and Psychology", 1(11), 23-28.

Kolshansky, G. V. (1990). An objective picture of the world in knowledge and language. Moscow: RAN INION.

Kondratyev, V. G. (1970). Sketch of the grammar of the ancient Turkic language. Leningrad: Izdatelstvo Leningradskogo Universiteta.

Kyzdarbekova, M. A., Serdali, B., Bakirova, Z. A., Nurtazayeva, N. M., Doszhan, S. M., Kasymbekova, K. A., Djamalova, S. A., \& Bimaganbetova, A. K. (2014). Nonverbal means of pedagogical dialogue in conditions of cross-culture communication. Life Science Journal, 11(Spec. Issue 6), 238-244.

Lalak, N. V., Vasylynka, M. I., \& Mayboroda, I. E. (2019). Use of sand therapy at the lessons of educational field "Arts" in terms of inclusion. Bulletin of Mukachevo State University. Series "Pedagogy and Psychology", 2(10), 147-149.

Lapshina, E. G. (2019). Vladimir Nikolaevich Voyeykov is a statesman, first "Minister of Sport", the entrepreneur. Bylye Gody, 51(1), 284-295.

Lapshina, E. G., \& Eshchin, D. V. (2020). Wooden houses of Penza Town of the 19th - Early 20th centuries and the problem of heritage preservation. IOP Conference Series: Materials Science and Engineering, 775(1), 012068.

Lavrenova, M. V., \& Fodor, K. J. (2020). Pedagogical terms and structural-functional model of forming sociocultural competence of future bachelors of arts in foreign languages on the principles of interdisciplinary integration. Scientific Bulletin of Mukachevo State University. Series "Pedagogy and Psychology", 1(11), 81-84.

Magsumov, T. A., Nizamova, M. S., Artemova, S. F., \& Allalyev, R. M. (2019a). The Akhal-Teke expeditions of 1879-1881 years: Historical and statistical study. Part 1. Bylye Gody, 53(3), 12561262.

Magsumov, T. A., Nizamova, M. S., Ponomareva, M. A., \& Allalyev, R. M. (2019b). The Akhal-teke expeditions of 1879-1881 years: Historical and statistical study. Part 2. Bylye Gody, 54(4), 17541760.

Malov, S. E. (1952). Yenisei writing of Turks: studies and texts. Moscow: Izdatelstvo AN SSSR.

Nadelyaev, V. M., Nasilov, D. M., Tenishev, E. R., \& Shcherbak, A. M. (eds.) (1969). Ancient Turkic dictionary. Leningrad: Nauka.

Panferova, I., \& Kim, Y. (2021). Conversion as a system-structural formation and lexical-semantic cohesion of terminological vocabulary. Journal of Language and Linguistic Studies, 17(1), 512516.

Pavenkov, O., Rubtsova, M., \& Shmelev, I. (2018). The transformation of gender visualization in photography: Soviet and Russian multisemiotics. Discursos Fotograficos, 13(24), 219-256.

Polivanov, E. D. (1968). Articles on general linguistics. Moscow: Nauka. 
Portnova, T. V. (2017). Genre art system: Experience of a comparative analysis of theatre (ballet, opera) and pictorial arts. Ponte, 73(8), 194-211.

Portnova, T. V. (2019). Self-determination of personality of creative beginning in choreographic context. Space and Culture, India, 7(2), 143-158.

Portnova, T. V. (2020). Art technologization in the context of theatrical science development. Astra Salvensis, 1, 701-729.

Sag̉yndykuly, B. (2002). Hibat-ul-Haqaiiq - XII edition. Almaty: Kazakh Publishing House Baspasy.

Sagyndykuly, B. (2011). The Turkic jazz era is the best of its kind. Journal of Altaic and Turkic, 4, 3138.

Sepir, E. (1934). Language. Moscow: Gosudarstvennoe Socialno-Economicheskoe Izdatelstvo.

Yensenov, K. A., Karasayev, G. M., Dyusen, S. Z., Naimanbayev, B. R., \& Islamov, M. K. (2019). The model of interethnic accord in the Republic of Kazakhstan (1991-2018): Historical research aspect. Analele Universitatii din Craiova - Seria Istorie, 35(1), 79-92.

Yıldırım, F. Ç. (2020). Language choice and identity: An investigation based on the comparison of language attitudes from two different localities. Journal of Language and Linguistic Studies, 16(2), 1032-1042.

Zholmakhanova, A. B., Tuyakbaev, G. A., Abdrazakov, K., Oralova, G. S., \& Serdali, B. K. (2018). Kazakh emigration and historical significance of memories of Mustafa Shokay. Utopia y Praxis Latinoamericana, 23(82), 111-120.

\section{AUTHOR BIODATA}

Nazgul B. Ilyassova is Doctoral Student, Department of Kazakh Linguistics, Al-Farabi Kazakh National University, Almaty, Republic of Kazakhstan.

Berikbay Sagyndykuly is Full Doctor in Philology, Professor, Department of Kazakh Linguistics, Al-Farabi Kazakh National University, Almaty, Republic of Kazakhstan.

Bakytgul Kulzhanova is Ph.D in Philology, Associate Professor, Department of Kazakh Linguistics, Al-Farabi Kazakh National University, Almaty, Republic of Kazakhstan. 